\title{
Religious Americans Have Less Positive Attitudes Toward Science, But This Does Not Extend To Other Cultures
}

\author{
Jonathon McPhetres ${ }^{1,2 *}$, Jonathan Jong ${ }^{3,4}$, Miron Zuckerman ${ }^{5}$
}

Word count: 3,426

${ }^{1}$ Hill/Levene Schools of Business, University of Regina

${ }^{2}$ Sloan School of Management, Massachusetts Institute of Technology

${ }^{3}$ Institute for Cognitive and Evolutionary Anthropology, Oxford University

${ }^{4}$ Centre for Advances in Behavioural Science, Coventry University

${ }^{5}$ Department of Clinical and Social Sciences in Psychology, University of Rochester

*E-mail: jon.mcphetres@gmail.com

\begin{abstract}
It is commonly claimed that science and religion are logically and psychologically at odds with one another. However, previous studies have mainly examined American samples: therefore, generalisations about antagonism between religion and science may be unwarranted. We examined the correlation between religiosity and attitudes towards science across 11 studies, including representative data from 60 countries $(N=66,438)$, nine convenience samples from the U.S. $(N=$ $2,160)$, and a cross-national panel sample from five understudied countries $(N=1,048)$. Results show that, within the U.S., religiosity is consistently associated with lower interest in science topics and activities, and less positive explicit and implicit attitudes towards science. However, this relationship is inconsistent around the world, with positive, negative, and null correlations being observed in various countries. Our findings are inconsistent with the idea that science and religion are necessarily at odds, undermining common theories of scientific advancement undermining religion.
\end{abstract}




\section{Introduction}

In 1875, John William Draper published his History of the Conflict between Religion and Science (Draper, 1875), and in 1896, Andrew Dickson White published in two volumes his $A$ History of the Warfare of Science with Theology in Christendom (White, 1896): ever since, the relationship between science and religion - Christianity in particular — has been widely seen as one of intrinsic antagonism. Just a few decades later, the events of the 1925 Scopes trial over a law in Tennessee forbidding the teaching of evolution in state-funded schools seemed to illustrate the point well. The "conflict thesis" has since become the dominant description of the relationship between science and religion, assumed by many members of the general public as well as by the media (Ecklund, Johnson, Scheitle, Matthews, \& Lewis, 2016; Funk \& Alper, 2015; Rios, Cheng, Totton, \& Shariff, 2015).

Social and psychological scientists have also recently theorised in this direction, offering explanations for why such a conflict might exist. For example, because religious people tend to deemphasize reflective cognitive styles, (Pennycook, Ross, Koehler, \& Fugelsang, 2016) athey may therefore find empirical science less attractive. Science and religion may also conflict epistemologically, because both provide competing avenues for understanding the world (Evans \& Evans, 2008). Additionally, secularization theories have proposed that, as people come to understand the world though science, they replace religious ideas and institutions with secular ones (Durkheim, n.d.; Norris \& Inglehart, 2011).

Although many of the events covered by Draper and White were European, both men worked in the United States, which has a unique religious history that might make the relationship between science and religion particularly difficult. For example, biblical literalism is rare in European Christianity, but commonplace throughout the United States from the twentieth century onward (Scott, 2006). The pervasiveness of this aspect of religious fundamentalism has impacted policy decisions throughout the United States. There have been multiple court cases since the Scopes trial 
concerning the teaching of evolution and creationism in public schools (Court of Appeals, 2016; Lewandowski, 2013) and several states have implemented policies to favour religious teachings over scientific teachings in the classroom (Agency, 2015; Baker, 2012; Mead \& Mates, 2009; Selman et al., 2005). In contrast, this has not happened in the United Kingdom or other European countries, including those for whom Christianity is the state religion. Additionally, there is some evidence that religious beliefs influence US Senators' legislative behaviours more broadly (Arnon, 2018). Other studies have also found that religiosity is negatively correlated with science knowledge (Jonathon McPhetres \& Zuckerman, 2018; Sherkat, 2011) and that religious people are less likely to choose careers in science (Scheitle \& Ecklund, 2016).

With few exceptions, almost all prior work on the relationship between religiosity and attitudes toward science has been conducted within the United States (Ecklund et al., 2016; Scheufele, Corley, Shih, Dalrymple, \& Ho, 2009). It therefore remains unclear whether the antipathy toward science evinced by American Christians is a fundamental characteristic of religious belief, or if it simply reflects a history and culture specific to the United States. Across 11 studies, we examined the relation between religiosity and attitudes towards science. We employed various measures of attitudes towards science and obtained data from the US and 61 other countries.

The religiosity measures differ somewhat among studies but all incorporated belief and/or practice items that are common to most religions. In our opinion, such measures are preferable to questions of religious affiliation as the latter might depend on factors (e.g., religiosity of parents, social ties, etc.) that have little to do with religious belief. In addition, the meaning of any specific affiliation differs among cultures, which makes interpretation of results more difficult. Gathering data from a number of countries and using varied measures of science attitudes with preregistered direct replications will increase generalizability of the results. 


\section{Section 1: Within the United States}

\section{Studies 1-5b}

Initial evidence for the negative relation between religion and science within the U.S. comes from nine original studies (see Table S1 for complete demographics). These studies were conducted in an attempt to experimentally manipulate the relation between science and religion. These attempts were not successful, likely because they relied on priming techniques that have been shown to be unreliable.

Particularly, the notion of priming in social psychology — that is, unconsciously activating one concept and then observing its influence on a subsequent concept — was a staple in social psychological research for many years. This body of evidence exists in an attempt to demonstrate that humans have little to no control over their thoughts, beliefs, and actions (Bargh, 1989). The basic assumptions of the technique are that the priming should be "incidental" and occur "without the person's awareness" (Bargh, Chen, \& Burrows, 1996; Williams \& Bargh, 2008), meaning that the two concepts should not seem to be related, but actually are. The participants' lack of awareness of the relation between the IV and DV is taken as evidence that the process is automatic (Bargh, 1989; Bargh et al., 1996).

A variety of studies relying on these priming techniques have been the subject of many recent replication attempts (for example, Caruso, Shapira, \& Landy, 2017; Chabris, Heck, Mandart, Benjamin, \& Simons, 2019; Harris, Coburn, Rohrer, \& Pashler, 2013; McCarthy, 2014; O’donnell et al., 2018; Pashler, Coburn, \& Harris, 2012; Rohrer, Pashler, \& Harris, 2015; Verschuere et al., 2018), none of which have been successful. Several further unsuccessful replication attempts focus specifically on priming concepts related to religion (Gervais, McKee, \& Malik, 2018; Gomes \& McCullough, 2015; Paulson et al., 2018; Sanchez, Sundermeier, Gray, \& Calin-Jageman, 2017; Saribay, 2020; Stagnaro, Ross, Pennycook, \& Rand, 2019; Verschuere et al., 2018). Thus, while not 
a focus of the present manuscript, these studies add to the mounting evidence that (behavioural or social) priming is unreliable and non-replicable.

Despite the lack of experimental effects, a negative correlation between religiosity and attitudes towards science was consistently identified across the studies and it is this result that we focus on in the present paper. Full details of each experiment are described in the supplementary materials

Method and Materials. Each study (with the exception of Study 1 and 2a) consists of an initial preregistered study (e.g. Study 3a) followed by a preregistered direct replication of that study (e.g. Study 3b). In each study, we used the same 6-item measure of religiosity (e.g. "I believe in God," "I consider myself religious" (Cohen, Shariff, \& Hill, 2008)) with higher scores indicating greater religiosity. The studies used a variety of techniques to "prime" either the concept of religion or science (see details in the supplementary materials), and then to observe effects on attitudes towards science or religion. The measures of science attitudes varied across studies; details are displayed in Table 1. 
Table 1. Descriptions of dependent variables used in Studies 1-5b.

\begin{tabular}{|c|c|c|c|c|}
\hline Study & Measure Name & Example items & Scale Range & $\alpha$ Reliability \\
\hline Study 1 & $\begin{array}{l}\text { Interest in } \\
\text { Science Topics }\end{array}$ & $\begin{array}{l}\text { Rated level of interest in } 30 \\
\text { topics presented } \\
\text { alphabetically: } \\
\text { Science topics (e.g. } \\
\text { biology, physics, robotics) } \\
\text { Neutral topics (e.g. books, } \\
\text { cars, music) }\end{array}$ & $\begin{array}{l}1 \text { (Not Interested) } \\
7 \text { (Extremely } \\
\text { Interested) }\end{array}$ & $\begin{array}{l}\text { Science: } \alpha=.94 \\
\text { Neutral: } \alpha=.74\end{array}$ \\
\hline $\begin{array}{l}\text { Study } 2 \mathrm{a} \\
\text { Study } 2 \mathrm{~b}\end{array}$ & $\begin{array}{l}\text { Explicit Science } \\
\text { Attitudes }\end{array}$ & $\begin{array}{l}\text { "It is not important to know } \\
\text { about science in everyday } \\
\text { life" (rev. coded) } \\
\text { "The world is better } \\
\text { because of science" }\end{array}$ & $\begin{array}{l}1 \text { (strongly } \\
\text { disagree) } \\
7 \text { (strongly agree) }\end{array}$ & $\begin{array}{l}2 \mathrm{a}: \alpha=.78 \\
2 \mathrm{~b}: \alpha=.68\end{array}$ \\
\hline $\begin{array}{l}\text { Study } 2 \mathrm{a} \\
\text { Study } 2 \mathrm{~b}\end{array}$ & $\begin{array}{l}\text { Implicit Science } \\
\text { Attitudes (IAT) }\end{array}$ & $\begin{array}{l}\text { Single category IAT; rating } \\
\text { science words (e.g. } \\
\text { laboratory, experiment) as } \\
\text { either Good (e.g. positive, } \\
\text { useful) or Bad (useless, } \\
\text { hurtful) }\end{array}$ & $\begin{array}{l}-2 \text { (more negative) } \\
+2 \text { (more positive) }\end{array}$ & - \\
\hline $\begin{array}{l}\text { Study } 3 a \\
\text { Study } 3 b\end{array}$ & $\begin{array}{l}\text { Interest in } \\
\text { Science Topics }\end{array}$ & $\begin{array}{l}\text { "We would like to get an } \\
\text { idea of the kinds of topics } \\
\text { you are interested in. Given } \\
\text { the opportunity, would you } \\
\text { like to read about the } \\
\text { following topics?" } \\
\text { Participants rated the same } \\
30 \text { topics from Study } 2 .\end{array}$ & $\begin{array}{l}1 \text { (Not Interested) } \\
7 \text { (Extremely } \\
\text { Interested) }\end{array}$ & $\begin{array}{l}\text { 3a } \\
\text { Science: } \alpha=.94 \\
\text { Neutral: } \alpha=.79 \\
\text { 3b } \\
\text { Science: } \alpha=.95 \\
\text { Neutral: } \alpha=.81\end{array}$ \\
\hline $\begin{array}{l}\text { Study 4a } \\
\text { Study } 4 \mathrm{~b}\end{array}$ & $\begin{array}{l}\text { Interest in } \\
\text { Science Topics }\end{array}$ & $\begin{array}{l}\text { "We would like to get an } \\
\text { idea of the kinds of topics } \\
\text { you are interested in. Given } \\
\text { the opportunity, would you } \\
\text { like to read about the } \\
\text { following topics?" } \\
\text { Participants rated the same } \\
30 \text { topics from Study } 2 .\end{array}$ & $\begin{array}{l}1 \text { (Not Interested) } \\
7 \text { (Extremely } \\
\text { Interested) }\end{array}$ & $\begin{array}{l}\text { 4a } \\
\text { Science: } \alpha=.94 \\
\text { Neutral: } \alpha=.81 \\
\text { 4b } \\
\text { Science: } \alpha=.94 \\
\text { Neutral: } \alpha=.81\end{array}$ \\
\hline $\begin{array}{l}\text { Study } 5 \mathrm{a} \\
\text { Study } 5 \mathrm{~b}\end{array}$ & $\begin{array}{l}\text { Science Interest } \\
\text { Scale }\end{array}$ & $\begin{array}{l}\text { "I like to watch television } \\
\text { programs about science" } \\
\text { "I would like to learn more } \\
\text { about the planets and stars" }\end{array}$ & $\begin{array}{l}\text { (strongly } \\
\text { disagree) } \\
7 \text { (strongly agree) }\end{array}$ & $\begin{array}{l}5 \mathrm{a}: \alpha=.92 \\
5 \mathrm{~b}: \alpha=.90\end{array}$ \\
\hline
\end{tabular}

Results. For each study, the measure of science attitudes was regressed onto the religiosity measure, experimental condition, and their interactions simultaneously. As shown in Figure 1, greater religiosity scores were negatively related to interest in science-related activities and to interest in reading or learning about science-related topics. Greater religiosity scores were also associated with more negative implicit and explicit attitudes towards science. These effects remained consistent while controlling for age, gender, education, and ethnicity. The main effect 
of religiosity and the partial correlations are depicted in Figure 1; regression coefficients are presented in the supplementary materials (see Table S2). Additionally, zero-order correlations yield highly similar results (see Table S3).

Figure 1. Correlations and confidence intervals for the relation between religiosity and various measures of science attitudes from nine studies within the United States. The forest plot depicts correlation coefficients (Pearson's $r$ ) controlling only for experimental condition; the partial correlations while controlling for demographics (age, gender, education, and dummy codes for ethnicity) are reported on the right-hand side of the figure.

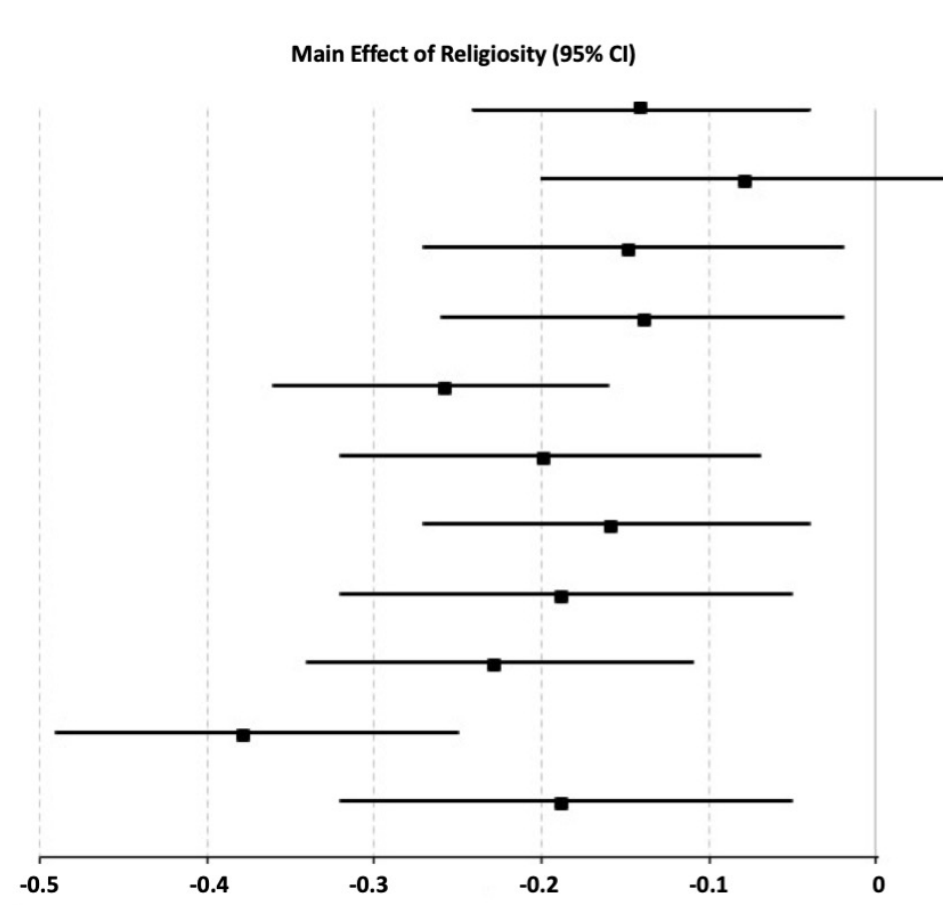

\begin{tabular}{|c|c|c|c|c|c|}
\hline \multicolumn{4}{|c|}{ Measure Details } & \multicolumn{2}{|c|}{ Partial Correlations } \\
\hline Study & DV Name & $N$ & $p$ & $r$ & $p$ \\
\hline Study 5b & $\begin{array}{c}\text { Science } \\
\text { interest scale }\end{array}$ & 371 & .008 & -13 & .015 \\
\hline Study 5a & $\begin{array}{c}\text { Science } \\
\text { interest scale }\end{array}$ & 275 & .177 & -.09 & .141 \\
\hline Study $4 b$ & $\begin{array}{l}\text { Interest in } \\
\text { science topics }\end{array}$ & 242 & .018 & -.15 & .019 \\
\hline Study 4a & $\begin{array}{l}\text { Interest in } \\
\text { science topics }\end{array}$ & 261 & .024 & -.14 & .024 \\
\hline Study 3b & $\begin{array}{l}\text { Interest in } \\
\text { science topics }\end{array}$ & 331 & $<.001$ & -.25 & $<.001$ \\
\hline Study 3a & $\begin{array}{l}\text { Interest in } \\
\text { science topics }\end{array}$ & 231 & .003 & -.13 & .061 \\
\hline Study 2b & $\begin{array}{l}\text { Implicit science } \\
\text { attitudes }\end{array}$ & 274 & .008 & -.29 & .002 \\
\hline Study 2a & $\begin{array}{l}\text { Implicit science } \\
\text { attitudes }\end{array}$ & 199 & .007 & -.19 & .011 \\
\hline Study 2b & $\begin{array}{l}\text { Explicit science } \\
\text { attitudes }\end{array}$ & 274 & $<.001$ & -.23 & $<.001$ \\
\hline Study 2a & $\begin{array}{l}\text { Explicit science } \\
\text { attitude }\end{array}$ & 199 & $<.001$ & -.38 & $<.001$ \\
\hline Study 1 & $\begin{array}{c}\text { Interest in } \\
\text { science topics }\end{array}$ & 200 & .010 & -.15 & .043 \\
\hline
\end{tabular}

\section{Section 2: Around the world}

\section{Study 6}

To examine whether the relations observed within the U.S. held around the world, we accessed the World Values and European Values Survey data (Inglehart et al., 2016) (WEVS) as an initial investigation. Data were available from 66,438 participants from 60 countries.

Materials. Science attitudes was measured using a composite of three items: "Science and technology are making our lives healthier, easier, and more comfortable," "Because of science and technology, there will be more opportunities for the next generation," and "The world is 
better off, or worse off, because of science and technology." Items were answered on scales ranging from 1 to 10 and were recoded such that higher scores represent more positive attitudes. The items were standardized and averaged together $(\alpha=.74)$. Religiosity was a composite of three items: "How important is religion in your life?", "How often do you attend religious services?", and "Do you consider yourself a religious person?". The items were standardized and averaged together $(\alpha=.73)$.

Results. We conducted a multilevel regression analysis using HLM (v7). At level 1, we used individual religiosity, age, sex, education, and political orientation to predict individual science attitudes. To investigate whether the link between religiosity and science attitudes depends on the country's average religiosity, we entered the average religiosity of each country at level 2 . Thus, we used country-level religiosity to predict the individual level religiosity and science attitudes correlation.

On average, there was a small negative correlation between individual religious belief and science attitudes above demographic controls across all countries, $\beta=-.027, p<.001$. However, the strength of this relationship varied depending on the average religiosity of the country, $\beta=$ $.034, p<.001$.

The slopes of each individual country are displayed in Figure 2, which is arranged in order of highest to lowest religiosity. While the correlation is associated with a p-value of $<.001$ in the United States ( $\beta=-.035,95 \%$ CI: $-0.044,-0.025], p<.001)$ as well as some other more secular countries (e.g. Sweden, $\beta=-.092,95 \%$ CI: $[-0.108,-0.076], p<.001$ ), the correlation is highly variable in other countries. 
Figure 2. Distributions and slopes of religiosity predicting science attitudes for each country. The $\mathrm{x}$-axis refers to religiosity and the y-axis refers to science attitudes; slopes are controlling for sex, income, political orientation, education, and age; shaded

band is $95 \% \mathrm{CI}$; panels are arranged from highest to lowest average country-level religiosity.

Nigeria

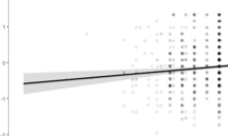

Morocco

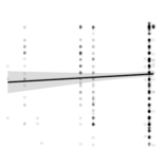

Libya

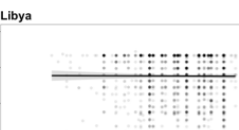

Palostine

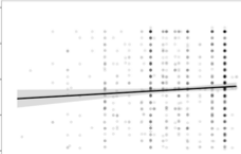

Malaysi

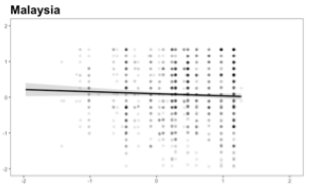

Brazil

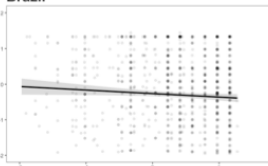

Turkey

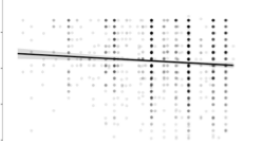

Thailand

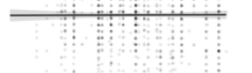

Argentina

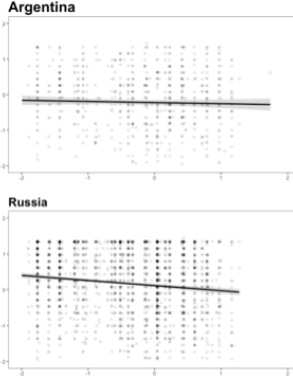

Uruguay

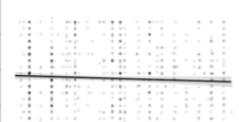

Netherlands

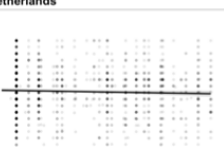

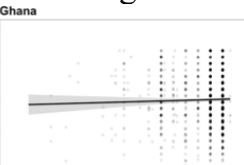

Pakistan

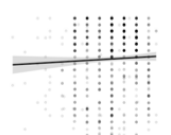

Georgia

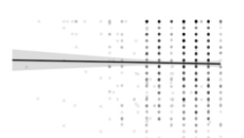

TrinidadTobago

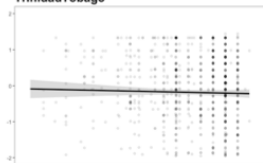

Ecuador

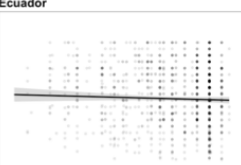

Poland

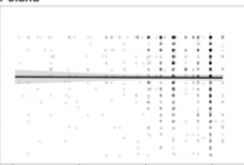

Armenia

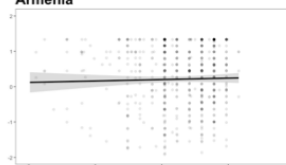

singapore

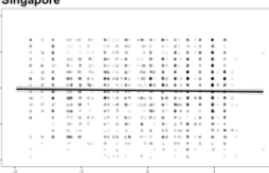

Chile

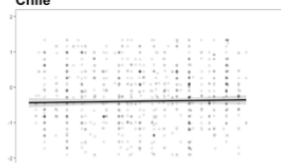

Azerbaijan

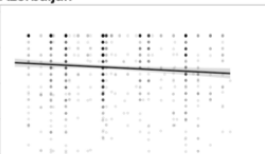

Australia

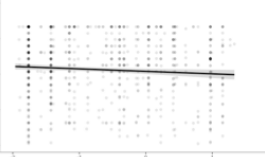

Estoni

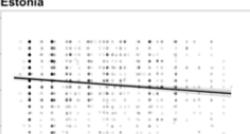

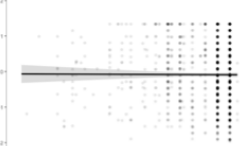

Rwanda

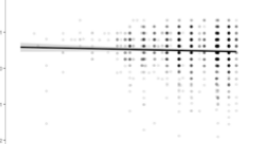

Algeria

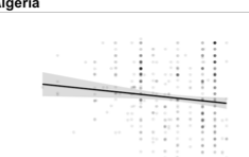

India

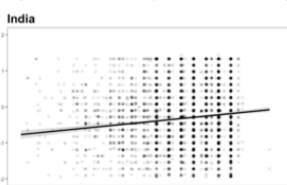

Tunisia
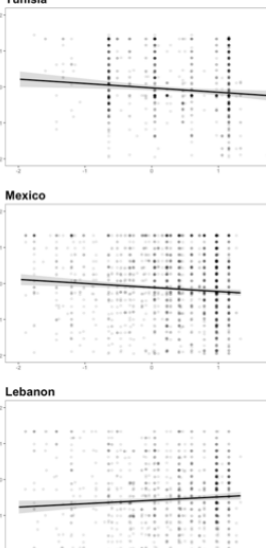

UnitedStates

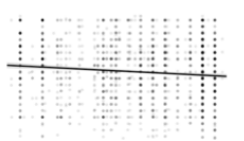

Kazaknstan

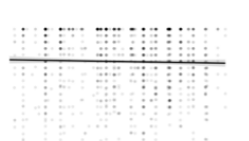

Taiwan

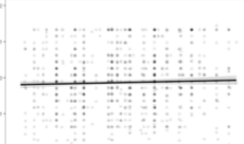

Japan

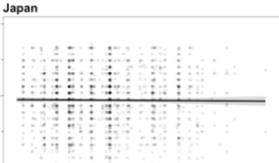

Sweden

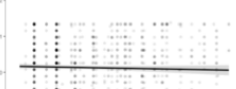

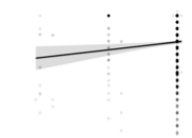

Jordan

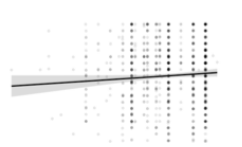

Bahrain
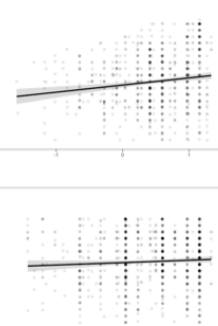

Southafrica

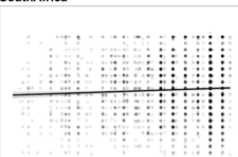

Romania
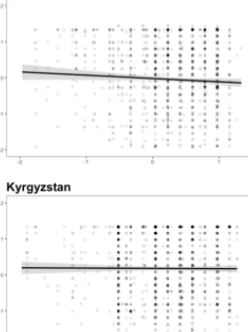

Ukraine

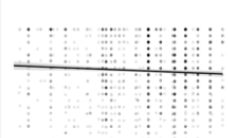

Uzbekistan
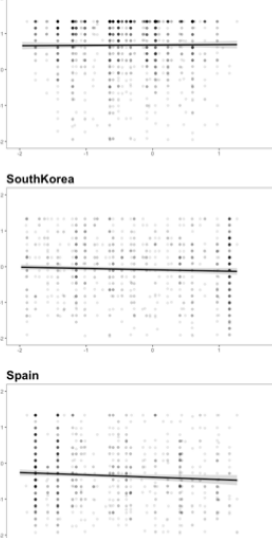

HongKong

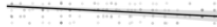

Philippines

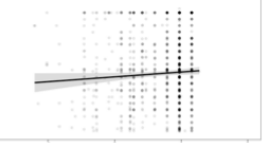

Yemen

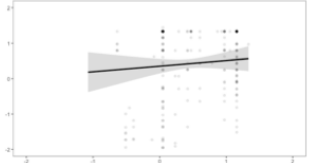

Kuwait

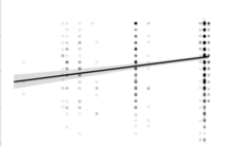

Egypt
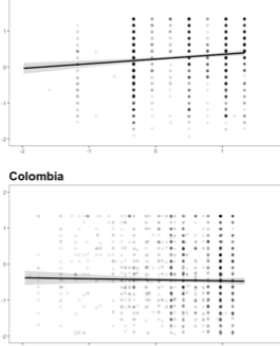

Peru

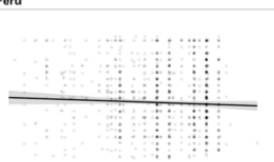

Cyprus

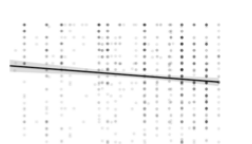

Belarus
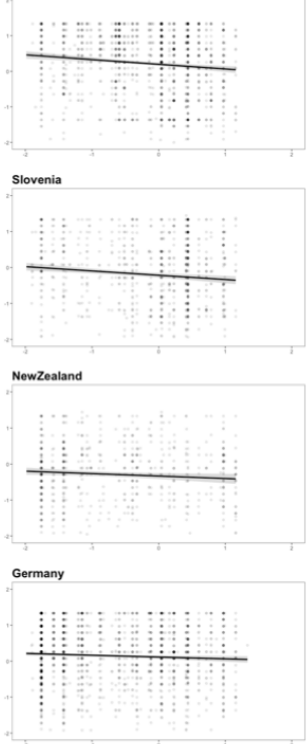

China

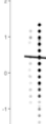


To provide additional context to the present results, a previous paper (Chan, 2018) undertook the similar task of analysing the data from the WEVS, but using a very different analytic approach. Namely, Chan analysed many items individually, used a different set of items to construct a religiosity measure, and also controlled for religious affiliation. It is reassuring that the results do not hinge on arbitrary analytic choices. Nonetheless, the present work replicates and extends these findings a great deal.

\section{Study 7.}

To further examine the relations between religion and science attitudes outside of the United States, we collected additional data in an attempt to examine the replicability of the findings from the WEVS.

Participants. In total, 1,048 subjects were recruited from five countries using Qualtrics Panels. The countries were Brazil $(N=210)$, Czech Republic $(N=210)$, Philippines $(N=208)$, South Africa $(N=210)$, and Sweden $(N=210)$. The countries were selected to represent a range of average country religiosity scores as observed in the WEVS data. Furthermore, the Czech Republic was not included in the WEVS, so this represents the first investigation of that country.

Materials. We used the science interest scale from Studies 5a-b and the explicit science attitudes scale from Studies 2a-2b. For each country, the surveys were translated into the dominant language and a back translator verified the accuracy of each translation.

Analytic plan. Our preregistered analysis plans included examining data from each country individually (https://osf.io/rfy $7 \mathrm{~h} /$ ). Results from these analyses can be examined in the supplementary materials (see Figure S1 and Tables S5-6). During the review process, it was suggested that we use a mixed-effects model, similar to the analysis conducted in Study 6, so we 
focus on this analysis here for simplicity. However, the results from both sets of analyses lead to substantially similar conclusions.

Results. In two linear mixed-effects models, we predicted science attitudes and science interest using person-level religiosity and the average religiosity for each country. We included demographics as controls (education, parental education, SES, age, gender, ethnicity, and political orientation) and random intercepts for each country. Full model results are available in Table S4.

Overall, religiosity was weakly and positively associated with science attitudes $(\beta=.07, p$ $=.044,95 \%$ CI: .010, .157) and science interest $(\beta=.10, p=.003,95 \%$ CI: .078, .208). However, person-level religiosity did not interact with country level religiosity for either science attitudes $(\beta=-.09, p=.093,95 \% \mathrm{CI}$ : .-.201, .025) or science interest $(\beta=.04, p=.504,95 \% \mathrm{CI}$ : $-.053, .154)$. The slopes and distribution of the data can be viewed in Figure 3.

Figure 3. Distributions and slopes of personal-level and country-level religiosity predicting science attitudes and science interest in Study 7.

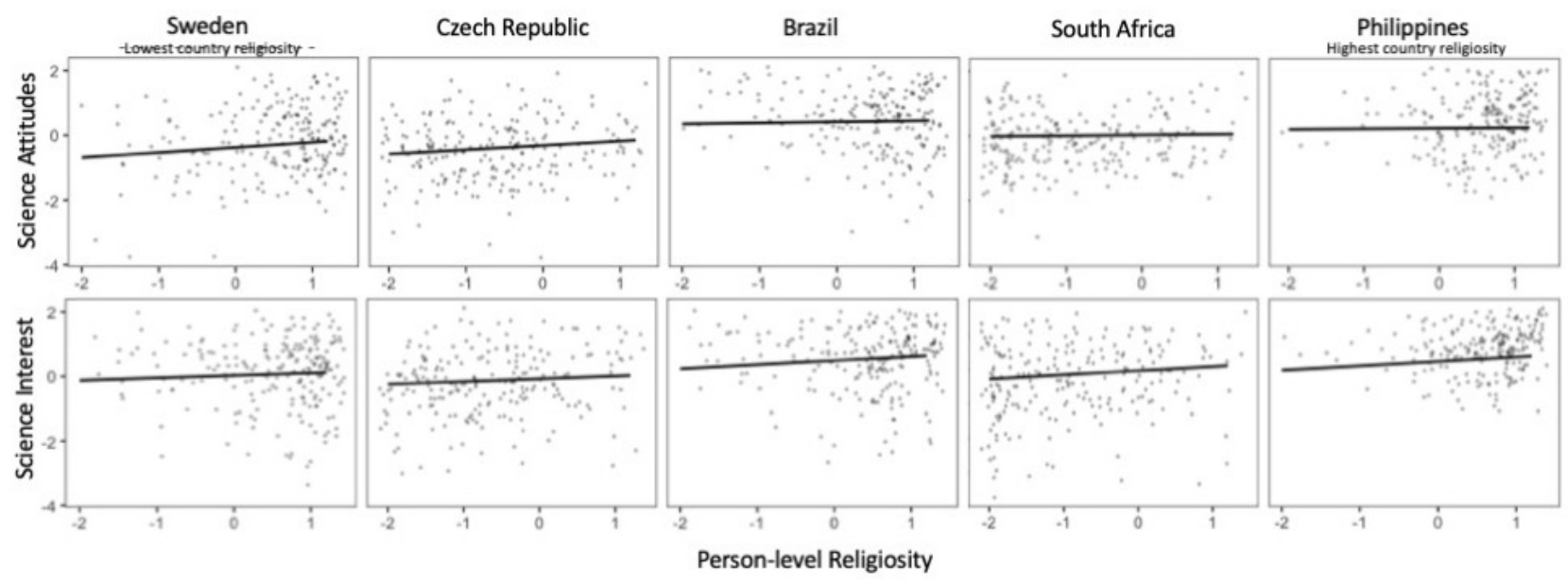




\section{Discussion}

In the United States, religiosity is consistently associated with more negative attitudes about (and less interest in) science. This was measured using various metrics: interest in sciencerelated activities, selection of science-related topics, general attitudes towards science, and implicit attitudes towards science. However, outside of the United States, these associations are inconsistent (with religion and science being positively correlated in some cases) and many are too small to be meaningful. Thus, while religion and science may have a unique relation within the United States, this apparent conflict is not at all generalizable to many countries around the world. This severely undermines the hypothesis that science and religion are necessarily in conflict.

To put the present results in context, past research suggests that few descriptive effects of religiosity reliably replicate outside of the United States. For example, a negative relation between reflective thinking and religiosity is widely replicated within the United States (Pennycook et al., 2016). However, one large-scale study found this effect to be clearly apparent in three of thirteen countries (Gervais, van Elk, et al., 2018) while another found it to replicate in India and the United Kingdom (Stagnaro et al., 2019). Further, some features of religiosity vary across cultures, such as pro-social behaviours resulting from beliefs in moralizing gods (Purzycki et al., 2016). On the other hand, moral prejudice against atheists seems to be a cross-culturally robust phenomenon (Gervais et al., 2017). The results of the present study suggest that correlations between religion and attitudes towards science may be unique to the United States.

Prevailing theories (Durkheim, n.d.; Norris \& Inglehart, 2011) and narratives (Coyne, 2016; Dawkins, 2016; Hitchens, 2008) suggest that religious belief necessarily leads to rejection of science. While the two accounts may sometimes offer contradicting narratives about some 
subjects, the present studies undermine these previous accounts as well as broader sociological accounts of scientific advancement undermining religion. Instead the results suggest that apparent conflicts may be the product of other socio-cultural and historical features of specific countries. Future research should continue to explore the historical and cultural narratives which may explain this pattern of findings. For example, the differential influence of biblical literalism (Scott, 2006), the overlap between fundamental religiosity and political conservatism (Gauchat, 2012), or various other patterns of cultural influence may be at work here.

There are strengths and limitations to consider. In this research we used many large samples, several preregistered analysis plans, and several direct and conceptual replications to arrive at our results. However, the data used here include both probability samples (the WEVS) and convenience samples (studies 1-5b) These limitations should be kept in mind. Still, the results we find are consistent across each data set used, suggesting that these results are easily replicable, at least within the U.S.

Much attention has been given to the questions of if (and how) religious and scientific cognition differ, and whether these differences or similarities are responsible for favouring one worldview over another. Clearly there are religious scientists (Ecklund \& Scheitle, 2007) and some research suggests that the fundamental elements underlying religious belief and scientific thinking are both natural and similar (Legare, Evans, Rosengren, \& Harris, 2012; Legare \& Visala, 2011). However other research suggests that the foundations of scientific and religious belief seem to diverge in many important ways (McPhetres \& Nguyen, 2018; Shtulman, 2013). Thus, it is important to take a comprehensive approach when examining whether religiosity is indeed predictive of one's orientation towards science. 
One particular strength of the present studies is that we utilized a wide variety of different measurements tapping into science attitudes in order to aid broad generalisation about exactly what science interest and attitudes mean. For example, science interest was measured by asking participants to choose various topics they found generally interesting - the list of topics comprised both scientific and non-scientific content. Further, we also asked participants to choose from a list of different topics they would like to read about. While such measures seem to be face-valid assessment of general interest, we also employed a science interest scale (Harty \& Beall, 1984) used in previous research (Jonathon McPhetres, 2019), which measures one's interest in specific science-related activities (e.g., going to science museums).

General attitudes towards science were measured via scales that are commonly employed in sociological research (Inglehart et al., 2016; Smith, Marsden, Hout, \& Kim, 2017). However, we also employed a widely used technique to assess implicit belief: the single-category implicit association test (Jong, Halberstadt, \& Bluemke, 2012; Karpinski \& Steinman, 2006; Nosek, BarAnan, Sriram, Axt, \& Greenwald, 2014). At the least, implicit measures are claimed to be less subject to presentation effects. Practically, however, an implicit measure may be no more than a much faster measure of attitudes which can either introduce noise or could help to reduce presentation effects. In the present studies, the implicit measure of attitudes towards science correlated positively with the explicit measure, suggesting it is at least similar.

Therefore, by taking such a broad approach, we are confident that we have accurately assessed both science interest and attitudes adequately. However, it is also important to note that we obviously did not measure actual behaviours, and it remains unclear whether interest and attitudes as operationalized in the present studies would correspond to physical behaviours. 
In conclusion, it appears that religious Americans have less positive attitudes towards, and less interest in, science. However, this does not appear to be a feature of religiosity, per se, as the effect is not clearly generalizable outside of the U.S. This research provides valuable evidence to inform applied approaches to science communication by understanding lay attitudes towards science. In countries where such a conflict narrative does exist, science communicators may benefit from knowing who distrusts science and why so that attitudes can be changed.

\section{Data Availability}

All data, syntax, and links to preregistrations are available on the Open Science Framework: https://osf.io/t7w6x/.

\section{Author Contributions}

$\mathrm{JM}$ is responsible for data collection, analysis, and drafting the manuscript; J.J. contributed to writing the manuscript, planned and oversaw data collection for Study 8; M.Z. supervised J.M. and provided feedback the manuscript.

\section{Competing Interests}

All authors declare no competing interests.

\section{Funding}

Studies 2-6 were supported by faculty funds from M.Z.

Funds for Study 8 were awarded to J.J. 


\section{References}

Agency, T. E. (2015). November 2015 Committee of the Full Board Work Session Item 1.

Arnon, D. (2018). The Enduring Influence of Religion on Senators' Legislative Behavior. Journal for the Scientific Study of Religion, 57(3), 567-584.

https://doi.org/10.1111/jssr.12535

Baker, J. O. (2012). Public perceptions of incompatibility between "science and religion." Public Understanding of Science, 21(3), 340-353. https://doi.org/10.1177/0963662511434908

Bargh, J. A. (1989). Conditional automaticity: Varieties of automatic influence in social perception and cognition. Unintended Thought, Vol. 3, p. 51. Retrieved from http://books.google.com/books?hl=en\&amp;lr=\&amp;id=HT6ddclz6EAC\&amp;oi=fnd\&a mp;pg=PA3\&amp; dq=Conditional+automaticity:+varieties + of + automatic + influence + in + so cial + perception + and + cognition\&amp;ots=dc2RLUrbyj\&amp;sig=gnKHVgl15Pen1KTPbW sAoGH6Wmo\%5Cnhttp://books.

Bargh, J. A., Chen, M., \& Burrows, L. (1996). Automaticity of social behavior: Direct effects of trait construct and stereotype activation on action. Journal of Personal and Social Psychology, 71(2), 230-244.

Caruso, E. M., Shapira, O., \& Landy, J. F. (2017). Show Me the Money: A Systematic Exploration of Manipulations, Moderators, and Mechanisms of Priming Effects. Psychological Science, 28(8), 1148-1159. https://doi.org/10.1177/0956797617706161

Chabris, C. F., Heck, P. R., Mandart, J., Benjamin, D. J., \& Simons, D. J. (2019). No evidence that experiencing physical warmth promotes interpersonal warmth: Two failures to replicate Williams and Bargh (2008). Social Psychology.

Chan, E. (2018). Are the religious suspicious of science? Investigating religiosity, religious 
context, and orientations towards science. Public Understanding of Science, 27(8), 967984. https://doi.org/10.1177/0963662518781231

Cohen, A. B., Shariff, A. F., \& Hill, P. C. (2008). The accessibility of religious beliefs. Journal of Research in Personality, 42(6), 1408-1417. https://doi.org/10.1016/j.jrp.2008.06.001

Court of Appeals, 10th Circuit. Cope v. Kansas State Board of Education. , 821 F.3d 1 Court of Appeals, 10th Circuit (2016).

Coyne, J. A. (2016). Faith versus fact: Why science and religion are incompatible. Penguin Books.

Dawkins, R. (2016). The God delusion. Random House.

Draper, J. W. (1875). History of the Conflict between Religion and Science. New York: Appleton.

Durkheim, E. (n.d.). The elementary forms of religious life. N/A, 414.

Ecklund, E. H., Johnson, D. R., Scheitle, C. P., Matthews, K. R. W., \& Lewis, S. W. (2016). Religion among Scientists in International Context. Socius: Sociological Research for a Dynamic World, 2, 237802311666435. https://doi.org/10.1177/2378023116664353

Ecklund, E. H., \& Scheitle, C. P. (2007). Religion among Academic Scientists: Distinctions, Disciplines, and Demographics. Social Problems, 54(2), 289-307. https://doi.org/10.1525/sp.2007.54.2.289

Evans, J. H., \& Evans, M. S. (2008). Religion and Science: Beyond the Epistemological Conflict Narrative. Annual Review of Sociology, 34(1), 87-105. https://doi.org/10.1146/annurev.soc.34.040507.134702

Funk, C., \& Alper, B. A. (2015). Religion and Science. Pew Research Center, (October). Retrieved from http://assets.pewresearch.org/wp-content/uploads/sites/14/2015/10/PI_2015- 
10-22_religion-and-science_FINAL.pdf

Gauchat, G. (2012). Politicization of science in the public sphere: A study of public trust in the United States, 1974 to 2010. American Sociological Review, 77(2), 167-187. https://doi.org/10.1177/0003122412438225

Gervais, W. M., McKee, S. E., \& Malik, S. (2018). Do Religious Primes Increase Risk Taking? Evidence Against “Anticipating Divine Protection” in Two Preregistered Direct Replications. PsyArxiv Preprint. https://doi.org/https://doi.org/10.31234/osf.io/8f7qd

Gervais, W. M., van Elk, M., Xygalatas, D., McKay, R., Aveyard, M., Buchtel, E. E., ... Bulbulia, J. (2018). Analytic atheism: cross-culturally weak and fickle phenomenon. Judgement and Decision Making, 13(3).

Gervais, W. M., Xygalatas, D., McKay, R. T., Van Elk, M., Buchtel, E. E., Aveyard, M., ... Bulbulia, J. (2017). Global evidence of extreme intuitive moral prejudice against atheists. Nature Human Behaviour, 1(8), 1-5. https://doi.org/10.1038/s41562-017-0151

Gomes, C. M., \& McCullough, M. E. (2015). The effects of implicit religious primes on dictator game allocations: A preregistered replication experiment. Journal of Experimental Psychology: General, 144(6), e94-e104. https://doi.org/10.1037/xge0000027

Harris, C. R., Coburn, N., Rohrer, D., \& Pashler, H. (2013). Two Failures to Replicate HighPerformance-Goal Priming Effects. PLoS ONE, 8(8), 1-9. https://doi.org/10.1371/journal.pone.0072467

Harty, H., \& Beall, D. (1984). Toward the development of a children's science curiosity measure. Journal of Research in Science Teaching, 21, 425-436.

Hitchens, C. (2008). God is not great: How religion poisons everything. McClelland \& Stewart. Inglehart, R., Haerpfer, C., Moreno, A., Welzel, C., Kizilova, K., Diez-Medrano, J., ... Puranen, 
B. (2016). World Values Survey Data File. Madrid: JD Systems Institute.

Jong, J., Halberstadt, J., \& Bluemke, M. (2012). Foxhole atheism, revisited: The effects of mortality salience on explicit and implicit religious belief. Journal of Experimental Social Psychology, 48(5), 983-989. https://doi.org/10.1016/j.jesp.2012.03.005

Karpinski, A., \& Steinman, R. Y. (2006). The single category implicit association test as a measure of implicit social cognition. Journal of Personality and Social Psychology, 91(1), 16.

Legare, C. H., Evans, E. M., Rosengren, K. S., \& Harris, P. L. (2012). The Coexistence of Natural and Supernatural Explanations Across Cultures and Development. Child Development, 83(3), 779-793. https://doi.org/10.1111/j.1467-8624.2012.01743.x

Legare, C. H., \& Visala, A. (2011). Between religion and science: Integrating psychological and philosophical accounts of explanatory coexistence. Human Development, 54(3), 169-184. https://doi.org/10.1159/000329135

Lewandowski, T. (2013). KANSAS 'S TWENTY-FIRST-CENTURY MONKEY TRIALS AND TRIBULATIONS : AN EXAMINATION OF THE STATE BOARD OF EDUCATION' 'S CONTINUING EVOLUTION VS . CREATIONISM CONTROVERSIES AND THE IMPLICATIONS FOR SCIENCE. International Journal of Arts and Sciences, 6(4), 437-449.

McCarthy, R. J. (2014). Close replication attempts of the heat priming-hostile perception effect. Journal of Experimental Social Psychology, 54, 165-169. https://doi.org/10.1016/j.jesp.2014.04.014

McPhetres, J., \& Nguyen, T. vy T. (2018). Using findings from the cognitive science of religion to understand current conflicts between religious and scientific ideologies. Religion, Brain 
and Behavior, 8(4), 394-405. https://doi.org/10.1080/2153599X.2017.1326399

McPhetres, J. (2019). Oh, the things you don't know: awe promotes awareness of knowledge gaps and science interest. Cognition and Emotion.

https://doi.org/10.1080/02699931.2019.1585331

McPhetres, J, \& Zuckerman, M. (2018). Religiosity predicts negative attitudes towards science and lower levels of science literacy. PLoS ONE, 13(11). https://doi.org/10.1371/journal.pone.0207125

Mead, L. S., \& Mates, A. (2009). Why Science Standards are Important to a Strong Science Curriculum and How States Measure Up. Evolution: Education and Outreach, 2(3), 359371. https://doi.org/10.1007/s12052-009-0155-y

Norris, P., \& Inglehart, R. (2011). Sacred and secular: Religion and politics worldwide. Cambridge: Cambridge University Press.

Nosek, B. A., Bar-Anan, Y., Sriram, N., Axt, J., \& Greenwald, A. G. (2014). Understanding and using the brief implicit association test: Recommended scoring procedures. PLOS ONE, 9(12), 1-31. https://doi.org/10.1371/journal.pone.0110938

O’donnell, M., Nelson, L. D., Ackermann, E., Aczel, B., Akhtar, A., Aldrovandi, S., ... Zrubka, M. (2018). Registered Replication Report: Dijksterhuis and van Knippenberg (1998). Perspectives on Psychological Science, 13(2), 268-294. https://doi.org/10.1177/1745691618755704

Pashler, H., Coburn, N., \& Harris, C. R. (2012). Priming of Social Distance? Failure to Replicate Effects on Social and Food Judgments. PLoS ONE, 7(8). https://doi.org/10.1371/journal.pone.0042510

Pashler, H., Rohrer, D., \& Harris, C. R. (2013). Can the goal of honesty be primed? Journal of 
Experimental Social Psychology, 49(6), 959-964. https://doi.org/10.1016/j.jesp.2013.05.011

Paulson, J. A., Camerer, C. F., Dreber, A., Holzmeister, F., Ho, T.-H., Huber, J., ... Wu, H. (2018). Evaluating the replicability of social science experiments in Nature and Science between 2010 and 2015. Nature Human Behaviour, 2(9), 637-644.

https://doi.org/10.1038/s41562-018-0399-z

Pennycook, G., Ross, R. M., Koehler, D. J., \& Fugelsang, J. A. (2016). Atheists and agnostics are more reflective than religious believers: Four empirical studies and a meta-analysis. PLoS ONE, 11(4), 1-18. https://doi.org/10.1371/journal.pone.0153039

Purzycki, B. G., Apicella, C., Atkinson, Q. D., Cohen, E., McNamara, R. A., Willard, A. K., ... Henrich, J. (2016). Moralistic gods, supernatural punishment and the expansion of human sociality. Nature, 530(7590), 327-330. https://doi.org/10.1038/nature16980

Rios, K., Cheng, Z. H., Totton, R. R., \& Shariff, A. F. (2015). Negative Stereotypes Cause Christians to Underperform in and Disidentify With Science. Social Psychological and Personality Science, 6(8), 959-967. https://doi.org/10.1177/1948550615598378

Rohrer, J. M., Pashler, H., \& Harris, C. R. (2015). Do subtle reminders of money change people's political views? Journal of Experimental Psychology. General, 144(4), e73.

Sanchez, C., Sundermeier, B., Gray, K., \& Calin-Jageman, R. J. (2017). Direct replication of Gervais \& Norenzayan (2012): No evidence that analytic thinking decreases religious belief. PLoS ONE, 12(2), 1-8. https://doi.org/10.1371/journal.pone.0172636

Saribay, S. A. (2020). Does intuitive mindset influence belief in God? A registered replication of Shenhav, Rand and Greene (2012). 15(2), 1-10.

Scheitle, C. P., \& Ecklund, E. H. (2016). Recommending a Child Enter a STEM Career. Journal of Career Development, 44(3), 251-265. https://doi.org/10.1177/0894845316646879 
Scheufele, D. A., Corley, E. A., Shih, T. J., Dalrymple, K. E., \& Ho, S. S. (2009). Religious beliefs and public attitudes toward nanotechnology in Europe and the United States. Nature Nanotechnology, 4(2), 91-94. https://doi.org/10.1038/nnano.2008.361

Scott, E. C. (2006). Creationism and evolution: It's the American way. Cell, 124(3), 449-451. https://doi.org/10.1016/j.cell.2006.01.028

Selman, J. M., Chapman, K., Silver, J., Mason, P., Jackson, T., Manely, M. E., ... Fant, L. G. Selman v. Cobb County School District. , 390 F. Sup Dist. COurt, ND Georgie 2005 (2005).

Sherkat, D. E. (2011). Religion and Scientific Literacy in the United States. Social Science Quarterly, 92(5), 1134-1150. https://doi.org/10.1111/j.1540-6237.2011.00811.x

Shtulman, A. (2013). Epistemic similarities between students' scientific and supernatural beliefs. Journal of Educational Psychology, 105(1), 199-212. https://doi.org/10.1037/a0030282

Smith, T. W., Marsden, P. V., Hout, M., \& Kim, J. (2017). General Social Surveys. Principal investigator Tom W. Smith.

Stagnaro, M. N., Ross, R. M., Pennycook, G., \& Rand, D. G. (2019). Cross-cultural support for a link between analytic thinking and disbelief in God: Evidence from India and the United Kingdom. Judgment and Decision Making, 14(2), 179-186. Retrieved from https://osf.

Verschuere, B., Meijer, E. H., Jim, A., Hoogesteyn, K., Orthey, R., McCarthy, R. J., ... Y1ldı, E. (2018). Registered Replication Report on Mazar, Amir, and Ariely (2008). Advances in Methods and Practices in Psychological Science, 1(3), 299-317. https://doi.org/10.1177/2515245918781032

White, A. D. (1896). A History of the Warfare of Science with Theology in Christendom. New York: Appleton.

Williams, L. E., \& Bargh, J. A. (2008). Experiencing physical warmth promotes interpersonal 
warmth. Science, 322(5901), 606-607. https://doi.org/10.1126/science.1162548 